\title{
SELÇUKLULARDA AV MERASIMLERI VE EMİR-İ ŞİKARLAR
}

\section{HUNTING CEREMONIES OF SELJUKS AND CHIEF FALCONERS}

\author{
Mehmet Ali HACIGÖKMEN*
}

\begin{abstract}
$\ddot{O} z$
Avcılığın insanlık tarihi kadar eski bir geçmişi vardır. İnsanoğlu, önce ihtiyacını gidermek ve varlıklarını sürdürebilmek için tüfek kullanımına değgin bir uğraş içinde olmuş ve birçok ritueller geliştirmiştir. Türklerin de yaşadıkları coğrafya nedeniyle avcılık yaşamlarının tam merkezinde olmuştur. Avladıkları hayvanların etleri ile ihtiyaçları gidermek ve kendi varlıkların sürdürürken derilerinden çizme, kürklerinden giysi ve kalpak, boynuzlarından yay ve müzik aleti, kemiklerinden kayak aracı yapmışlar, ayrıca avı, savaşa hazırlanmanın en önemli tatbikatı olarak görmüşlerdir. Selçuklularda atalarının av kültünden hiç vazgeçmemişler, hem Büyük Selçuklu hem de Türkiye Selçuklu Sultanları şaşalı av törenleri düzenlemişler, toylar (ziyafetler) vermişlerdir. Sadece av işleri ile uğraşan Emir-i Şikar (bazdar) adı verilen emirler bulunmuş, Sultanın av törenlerinde kullanılacak kuşların eğitilmesi, kullanılmasına kadar av ile ile ilgili ne varsa onunla ilgilenmişlerdir. Bu çalışmada Türkiye Selçuklu Sultanlarının av törenlerini, av emirlerinin (emir-i şikar) görevlerinin ne olduğu anlatılmaya çalışılacaktır.
\end{abstract}

\section{Anahtar Kelimeler}

Emir-i Şikar (Av Emiri), Şikarhane (Avhane), I. Alaeddin Keykubat, Avlak.

\begin{abstract}
The history of hunting is old as the human history. The humans have been dealing with many activities to cover their needs and continue their existence till learning the usage of rifle and therefore created many rites.. The hunting was at the centre of Turkish people life related with their geography in which they lived. They cover their needs and continue their life by means of the meat of the hunted animals and made boots from their skins, made clothes and cap from their fur, made arch and musical instruments from their horns and made skiing vehicles from their bones. Also they thought the hunting as the most important practice before wars. The Seljukians didn't give up the cult of hunting derived from their ancestors, both the sultans of the Great Seljukian State and the Turkey Seljukian State organized glorious hunting ceremonies and prepared meals called as "toy" for their guests. There were rulers called as "Emir-i Şikar (bazdar)" who were merely busy with the hunting activities and they always dealt with all of the duties covering the hunting such as the training of the birds that would participate to the hunting ceremonies. The Sultans of the Turkey Seljukian State, especially Sultan Alaaddin Keykubat I, built many hunting lodge called as Şikarhane in many locations of the
\end{abstract}

* Doç. Dr. , Selçuk Üniversitesi Edebiyat Fakültersi Tarih Bölümü Öğretim Üyesi, hgokmen selcuk.edu.tr 
state. In this study, we would like to give information on hunting ceremonies of the Sultans of the Turkey Seljukian State and where did they build the avlak and avhane (hunting grounds and hunting lodge) and the tasks of the hunting rulers called as "Emir-i Şikar.

\section{Keywords}

Emir-i Şikar (the ruler of hunting), Şikarhane (Hunting lodge), I. Alaeddin Keykubat, Avlak (Hunting Ground). 


\section{Giriş}

Av, Türklerin yaşamında önemli bir yeri ve anlamı vardı. Önce ihtiyaçları gidermek ve kendi varlıklarını sürdürebilmek için yapılıyordu. Avladıkları hayvanların etleri ile varlıklarını sürdürürken, derilerinden çizme, kürklerinden giysi ve kalpak, boynuzlarından yay ve müzik aleti, kemiklerinden kayak aracı yapmakta idiler. Tabi ki av savaşa hazırlanmanın en önemli tatbikatı idi

Türk askerlerini yerli ve yabancı kaynaklar, daima kurtlara benzetmişlerdir (Kafesoğlu 1998: 287-288). Bunun sebebi de avc1lıta askerlerin zinde ve çevik kalmaları idi. Kültigin yazıtında böyle benzetmeler vardır: "Tanrı güç verdiği için babam kağanın askeri börü (kurt) gibi, düşman koyun gibiymiş" (Ergin 1980: 6), şeklinde tanımlama buna çok güzel bir örnektir. Avcılık, Şamanizm içerisinde oldukça önemli bir yere sahip idi. Şamanın görevleri arasında av büyüsü adlı bir büyü vardı. Şaman bu büyü ile av hayvanı ve doğa ruhlarıyla irtibata geçerdi. Böylece şamanın en büyük görevi olan av hayvanlarının kıtlaşmasını önlemek olurdu (Ergüzel, 2009: 47). Ayrıca avcı kelimesinin bazı Türk lehçelerinde vahşi hayvan anlamına gelen ançı kelimeden türemiş olması (Berbercan 2010: 11; Bayat 2009: 1-11) da Türkler'de avın ne kadar önemli olduğunu göstermesi bakımından önemlidir.

Yukarıda ifade ettiğimiz gibi Türklerin en eski geleneği olan avcılığı, Oğuzlar fazlasıyla devam ettirmişlerdir. Her şey Oğuz töresine (resmine) göre yapılırdı. Bu törenin dışına çıkan veya çıkmaya çalışan dışlanırdı. Av hazırlığından tutunda av esnasında yapılacaklar ve avlanan hayvanların taksimi ve hatta kemikli kemiksiz şekilde yenmesine kadar Oğuz resmine (töresine) uymak gerekiyordu. Yazıcızade Ali, Tevârih-i Âli Selçuk adlı eserinde bunu şöyle ifade eder:

Hanlar atası Ŏguz Han söyledi;

Böyle töre yol erkan eyledim

İşbu resm ile vasiyet kuldı ol

Tâ ola oğlanlarına töre yol... (Yazıcızâde Ali 2009: 341, 351; Önder 2009: 17).

Oğuz beyleri ava çıkmadıkları zamanı boşa geçmiş bir gün olarak görürlerdi. Dede korkut kitabında her hikayede en az bir av motifi bulmamız mümkündür. Oğuzlar avlardan sonra büyük toylar yemekler verirlerdi. Bu Yazıcızâde bu durumu şöyle ifade eder: "...ve haftada iki gün meydana çıkıp top ve çevgan oyunu oynarlar ve silahşörlük ok atmak idmanın iderlerdi. Ve bezm ve şerab sohbetin dahi evkat $k i$ is ve maslahat olmasa eyyamda bir kerret iderdi. Ve zurefâ ve hurefa ve nedemâ ve şuaraya slla ve hil'a ve bahşiş virürdi... (Yazıcizâde Ali 2009: 351; Önder 2009: 18) Bu geleneğe Oğuz boyunun kurduğu en büyük devletler olan Selçuklu devletlerinin Sultanları da harfiyen uymuşlardır (Turan 1988: 30-33). Bu konu hân-1 yağma (toy, büyük toy) başlığı altında aşağıda anlatılacaktır. Çalışmamızda Türkiye Selçuklulardan örnekler verilirken Oğuz boyunun diğer büyük devleti Büyük Selçuklulardan da örnekler sunulacaktır.

\section{Sürek Avları}

Sürek avları günlerce sürecek faaliyetler silsilesini ve askerlerin hem bedenî, hem de manevra kabiliyetlerinin geliştirilmesini sağlayan av türüdür. Sürgün avları uzun soluklu olurdu (Türkmen 2009: 21). Sığır avıyla, sürgün avından bahseden Kaşgarlı Mahmut, bunu Hanların tebaasıyla yaptığın bir nevi av olarak tarif ettikten sonra bunun, Hakanın maiyeti 
ormanlara ve kırlara dağılıp yabanî hayvanları Hanın önüne sevk ettiklerini, onunda önüne gelen hayvanları öldürmek suretiyle yapıldığını (Kaşgarlı Mahmud 2006: 303) söyleyerek Selçuklulardan evvel dinî mahiyetini kaybeden bu av merasimlerinin varlı̆̆ını meydana koyar. Sürgün avına Safeviler döneminde halka avı denirdi (Şükürov 2009: 57-58). Yani bu bir tür avlanmada belli bir bölgede mevcut olan yabanî hayvanlar bir süre kovalanarak dar bir alanda halkaya alınır ve bundan sonra aynı bölgede büyük bir av şenliği kurulurdu. Sürgün avında avcılar tarafından oluşturulan kuşatma çemberi, toplama yerine doğru, av hayvanları ürkütülmeden yavaş yavaş daraltılırdı. Tabii bu arada büyük hayvanlar için hazırlanan kafesler hazır tutulur, kapan gibi av hayvanlarına tuzaklar kurulur, çukurlar kazılır ve üzerleri yaprak, çalı çırpı ile örtülürdü. Bu şenliğe Hakanın, aile ve efradı, devlet ileri gelenleri ve ordu mensupları katılırdı. "Halka"yı oluşturabilmek için bazı durumlarda, avlanma yerinin ahalisi de seferber ediliyordu. Ava ilk önce Oğuz töresince Hakan kendi hasekileriyle oğlanlarıyla ve beyleriyle halka içine girip başlar (Yazıcızâde Ali 2009: 351-352) ve yorulunca yüksek bir yere çekilir, oradan av şenliğini seyrederdi (Şükürov 2009: 58-59). Hakandan sonra melikler, diğer ümera sırasıyla devlet ileri gelenleri ve ordu mensupları da av mutluluğunun tadına varırlardı. En son daha aşağıdaki beylere ve sipahilere destûr verilirdi (Yazıcızâde Ali 2009: 351-352; Roux, 1994: 180).

Bu av sahnesini Konya Alaeddin sarayından İstanbul Türk ve İslam Eserleri müzesine getirilen Alaeddin Keykubat dönemine (1220 -1237) tarihlenen alçı kabartmada görebiliriz (Öney 1969: 134). (Ek-1) Burada karşılıklı iki atlıdan soldaki bir ejderi, sağdaki bir arslanı kılıçlamaktadır. Atlar hareketleri ve koşum takımları ile oldukça realist işlenmiştir. Sağdaki atlı, arkadan ata saldıran arslanı geriye dönerek iki eliyle tuttuğu kılıçla ağzından vurmaktadır (Öney 1969: 134). Bu sahne Selçuklu Sultanının sürgün avındaki sahnesinden başka bir şey değildir. Sultan avlandıktan sonra, Sultanın isteği doğrultusunda avlanma durdurulur ve avlanmış hayvanlar paylaştırılırdı. Ancak bu paylaştırmada o kadar ileri gidilir ki ziyafetlerde oturan beylere kemikli ve kemiksiz kısımlara gelip gelmeyeceği bellidir (Şükürov 2009: 58; Önder 2009: 17). "Sultan kuşluk vaktinde değin müfti ve kadı huzurunda kendisu hükm edip malûmlara dâd (adalet) verirdu. Şer'i ve divân̂̂ kendü görürdü. Şer'i işi ehl-i şer meşveret-i fasıla yitirürdü. Kendüsü divaniye cevap verirdi.....andan sonra hân ve şöylân dökilürdi kendü öninde ve iki tarafda iki kolda somât ve destâr hânlar döşenürdi. 'Âlim ve seyyidler ve müfti ve kâzi ve ulu şehzadeler kendü-ile bile yerleridi. Kalan beğler ve ulular iki kolda mertebelü mertebesince somâta otururlardl, hâssa sögüş ve sögülme ve biryândan Oğuz resmince her hânun ve melikün sünüklü sünügin korlardl. ...dâne ve zerde ve nârdeng ekşileri ve mastâva ve börekler dökilürdi. Şöyle ki oturanda ve turanda kimesne mahrüm kalmazıdı (Yazıcızâde Ali 2009: 350). Bu konuda Ebulgazi Bahadır Han ise, hayvanı kimin tuttuğuna ve doğradığına dair paylaşma işini dahi tüm ayrıntılarıyla verir. "İmdi on ikki örgede olturup ülüş alğan kim ve ol ülüşni toğrağan kim taşkarıda atların tutup olturğan kim, anlarnı beyân kılalıy: Altun örgenin törinde Kün Hân olturdı. Barça il yahşıları ittifâk kılıp koynın başın ve arkasın kuyruklı uçasın ve bağrnn uçanın üstinde koyup Kün Hânnın aldında koydılar, hem kim hân bolsa ülüşleri bu bolsun tidiler. Örgenin içki işikinde Irkıl Hâce olturdı. Töşni anın aldında koydılar takı hem kim vezir bolsa, anın ülüşi bu bolsun tidiler. Să̆ kolda evvelki örgede Kün Hânnın uluğ oğhı Kayını olturdılar. Să̆ aşuklı iliki ülüş bedriler. Bayat anı toğradı. Sorkı atların tutdı" (Ölmez 1996: 155; Önder 2009: 17). Tasvir edilen avlanma şekline ortaçağlar boyunca Moğollarda da rastlamaktayız ${ }^{1}$. Burada görünen o ki av hayvanlarının tamamı öldürülmüyordu. Çünkü kutsal bilgiyi unutan ve avı eğlenceye çeviren avcının, önüne çıkn her şeyi avlaması, cezalandırılmayla sonuçlanırdı. Böylece yeni bir av için hayvanların çoğalmasını sağlanıyordu. Av sırasında bazı hayvanların avlanması ise Özellikle Oğuz boyları arasında çok yaygın olan bu avlanma şekli “Oğuz töresi ile avlanma” ismini taşımakta idi.
Moğollardaki avlanma şeklinin ayrıntılı tasviri için bk. (Dohsson 1340-1342: 174-175; Şükürov 2009: 59). 
kesinlikle söz konusu değildi. Asil kabul edilen bu hayvanları (geyik, yabani sığır) avlamak ancak hükümdarlara aitti (Esin 2006: 203; Selçuk 2004: 245). Dede Korkut Hikâyelerinde, geyik avının kutsallığı ile ilgili hikayelerde bilgiler geçmektedir. Begil Oğlu Ermen Hikayesi buna çok güzel bir örnektir². Av sonrası ise av hayvanına karşı saygısızlığın yapılmaması, av hayvanının belirli yerlerinin yenmemesi ve loğusa kadınlara av etinden yedirilmemesi gerekmektedir. Dede Korkut hikâyelerinde ve günümüz Türkiye coğrafyasında da görmek mümkündür (Öncül 2009: 1685; Ergin 1989: 84).

\section{Kuş Avları}

Bunlar törensiz yapılan avlar, kısa süre için az bir personelle ve saraya yakın yerlerdeki, av bölgelerinde yapılan avlardı (Türkmen 2009: 24). Kuş avı çeşitli şekillerde yapılırdı. Avcılar halka oluşturup avın çıkartılan gürültüyle kapatılan kaçma yollarına uçması sağlanır, yırtıcı kuşlar uçurulduktan sonra, ardından tazılar ve zağarlar salınmış ve yırtıcı kuşlar havadan avın üzerine dalış yapar iken, gözden kaybolmasınlar diye atla takip edilirdi. Kuş avında kullanılan bu yöntem en muteber yöntem idi. Türk savaş tekniğiyle benzerlikler gösteren bu avlanış tarzı Türkler için bir çeşit savaş idmanı olma niteliği kazanmıştır (Berbercan 2010, 20). Bu yöntemi Türkiye Selçuklu Sultanları çok kullanmış görünüyor. Bu av tasvirini Afyon Boyalı köyden Afyon müzesine götürülen figürlü mezar taşında görebilmekteyiz (Otto-Dorn 1959: 63-76; Öney 1969: 128-129). Burada aşağıda daha tafsilatlı anlatılacağı gibi av esnasında elinde avda gürültü yaparak kuşların havalanmasına yarayan davul, tokmak, veya benzer aletler bulunan atlı grup vardır $^{3}$ (Ek-2). Bu tasvirde çıartılan gürültüyle kaçma yolları kapatılan kuşlar sultanın elindeki avcı kuşlarla avlanmaktadır. Avcı kuşlarla yapılan av, tüfekler ortaya çıkana dek kullanılmıştır. Bunun dışında az da olsa farklı yöntemlerde kullanılmıştır. Bunlardan birisi yine gürültüyle kuşları uçurtarak keçi kılından örülmüş mükemmel ağlarla yakalamak idi. Bir diğeri ise karanlık ve yağmurlu gecelerde okun ucuna bağlanan ince bir ağla akarsu boylarından havalanan kuşa atılır ve ağ kuşun kanatlarına dolanır idi (Berbercan 2010: 21). Kuş avları günübirlik ve kısa süreli de yapılabilirdi. Kuş avları sabır, teknik incelik ve emek isterdi. Yırtıcı kuşların yuvalarının tespiti, yavruların daha yumurtada iken takip edilmesi, belli bir büyüklüğe ulaşınca alınıp eğitilmeleri zor bir iştir. Bu işleri doğancı, şahinci ve atmacacılar adlı görevliler yapardı (Türkmen 2009: 25-26). Kuş Avlarında genellikle doğan, atmaca, şahin gibi yırtıcı kuşlar, tavşan, keklik, yaban ördeği, kaz, toy kuşu, kuğu ve bıldırcın gibi kuşların avında kullanılmışlardır (Türkmen 2009: 25-26; Güven 1999: 153-154). Bunların içinde en elverişlisi atmacadır. Bu özelliğini kolay eğitilmesi ve insana sadık olmasındandır. Atmaca yırtıcılığa elverişli vücut şekli, tüylerinin muntazamlığı, omuzlarının genişliği, gagasının iriliği ve gözünün keskinliği üstün özelliklerini ortaya kıyar.

\section{B. Selçuklularda Avcılık Bir Çeşit Savaşa Hazırlık ve Tatbikat Olarak Yapılmıştır.}

Selçuklular bütün Türk devletlerinde olduğu gibi savaşlardan önce veya barış zamanlarında harp taklidi niteliğinde büyük sürgün avları düzenlemişlerdir. Bunu en çok

2 Oğuzlar'a her yıl altın, gümüş olarak gelen haraç bir sene at-kılıç ve çomak olarak gelir. Oğuz Beyi çok sinirlenir. Ama yanındakiler sinirlenmemesini söyler. 'Bunları Begil denilen bir yiğit var, ona verelim, bize duacı olsun' der. Begil çok yetenekli bir avcı ve çok iyi bir yiğittir. Geyikleri ok atmadan sadece ipiyle avlar. Kazan Bey 'hüner sende midir atta mıdır' diye sorunca bendedir dedi ancak Kazan buna katılmadı. Buna üzülen Begil hediyeleri geri verir küser ve oradan ayrılır. Evine döner ve ava çıkar. Avda ayağını kırarak sakatlanır. Önceleri kimseye söylemedi ama bu herkese yayıld1. (Ergin 1989: 117).

3 Bkz. (Lindner 1972; Müler 1965) Avcı kuşların eğitimi ve avlanmasını detaylı olarak bu eserler de anlatmaktadır. 
Türkiye Selçuklu Sultanı I. Alaeddin Keykubat yapıyordu. Önemli bir sefer öncesinde Kayseri, Beyşehir Kubadabad, Alanya' daki av sahalarında av yapmakta idi (İbn Bibi 1957: 132, 140, 154, 162, 163, 168, 169, 171, 182, 204, 247, 272-73, 352-54, 356, 415, 418, 424; İbn Bibi, 1996: 152, 174,182-83, 188, 200, 222, 290, 361, 365, 357, 417). Bu da ordunun sefere hazır hale gelmesini sağlamakta idi. Ayrıca önemli kararlarını ve kabullerini bu av sonrası verilen toy'dan sonra yapmakta idi. Bundan dolayı da Sultan, av meclislerine maiyeti ile beraber devlet ileri gelenleri ve ordu mensupları da katılıyordu. Av meclislerine katılan askerler ok atmak, kılıç sallamak, kement atmak, gürz kullanmak ve mızrak atmak suretiyle askerî maharetlerini zinde tutmuş ve savaş alışkanlıklarını yenilemiş oluyorlardı. Bizce av törenlerinin amacı sadece bununla da kalmıyor, aynı zamanda hesapların yapıldığı, planların kurulduğu, zorlukların aşıldığı, devlet meselelerinin çözüldüğü bir saha oluyordu.

$\mathrm{Bu}$ ananeye Büyük Selçuklular'dan da örnek verecek olursak Alp Arslan'ın Malazgirt savaşından önce Suriye'den Bizans İmparatoruyla savaşmak üzere dönerken uğradığ 1 Meyyafarikîn'de (Silvan) bir ara avlanmaya çıkmıştı. Burada Alp Arslan'ın Malazgirt savaşı gibi büyük karşılaşma öncesi zevk ve eğlence için ava çıktığını söylememiz mümkün değildir. Bu ava Alp Arslan yanındaki askerlerin savaşa manen hazırlamak için çıktı̆̆ını söylememiz gerekir. Hatta bu av Sultan'ın Bizans ile savaş öncesi plân yapmaya, ve düşünmeye fırsat bulduğu bir tatbikat olmalıdır. Bu avın birkaç gün sürdüğünü kaynaklar haber vermektedir (Köymen, 2000: 121). Alp Arslan Malazgirt savaşını kazandıktan sonra mağlup Bizans İmparatorunu yanında doğanı ve av köpeği olduğu halde huzuruna aldığı ona izzet ikram ve lütufta bulunduğunu biliyoruz (Sümer-Sevim 1971: 17, 28, 39-40,51, 53-54).

\section{Av Sonrası Büyük Toy (Han-ı Yağma, Ziyafetler).}

Selçuklu Sultanları toy denilen millî ananeyi devam ettirmişlerdir. Bu anane bütün Türk Devletlerinde olduğu gibi Selçuklularda hâkimiyet alâmeti idi (Taneri 1997: 435). Sultan tahta çıktığı zaman cömert ve zengin olduğunu göstermeli idi" Yani Bilge Kağan'ın dediği gibi “aç milleti doyurup, çıplak milleti giydirmeli" idi (Ergin 1980: 19, 25). Bunun için Sultan saçı saçar $($ ulufe) 5 her büyük av töreninden sonra büyük toylar, (han-ı yağma, ziyafet) verirler idi (Yavaş 2003: 155-162). Bunu av-hanelerin (şikarhaneler) yapımında da görmek mümkün. Bu yapılar konum olarak, geniş arazilerin manzaraya en hâkim bölümünde yapılmışlardır (Yavaş 2003: 155-162). Demek ki büyük toylar geniş alanlarda verilmekte idi. Avdan dönüş, av etlerinden hazırlanmış büyük toylar (ziyafetler) sona erdikten sonra, musikî, çevgan cirit, satranç bu ziyafetlerin revnakını arttırırdı (İbn Bibi 1957: 132, 140, 154, 162, 163, 168, 169, 171, 182, 204, 247, 272-73, 352, 356, 415, 424; İbn Bibi 1996: 152, 174,182-83, 188, 200, 222, 290, 361, 365, 357, 417).

Selçuklu Sultanları av yapmağa bir aşk derecesinde bağlı idiler. Avlanılan kuşlar ve hayvanların şer'an günah olmadığını ortaya koymaya çalışmışlardır. I. Glyaseddin Keyhusrev'in avdan neşelendiğini için bir Arap atına av satın aldığını yani avladığı hayvanlara karşılık Arap

4 Bu anlayışın hükümdara yüklediği en önemli vazife, halkı ve etrafındakileri doyurmaktır. Bu sebeple hükümdarlar her zaman sofralarını halka açı tutarlardı (Râvendî 1957; 25, 107, 206; Genç 1981; 89).

5 Moğollarda "saçu" şeklinde söylenen Türkçe kökenli bu kelime, Azerbaycan ve Türkmen Türkçesinde "sepmek", Başkurt Türkçesinde "sasiv"; Kazak Türkçesinde "şaşuv", Kırgız ve Tatar Türkçesinde "çaçû", Özbek Türkçesinde "saçmak", Uygur Türkçesinde "çamçak" , olarak geçer. (Ercilasun 1992: 730-31); Buna Türk tarihinde birçok örnek vardır. Sultan II. Kılıçarslan'ın ölümü üzerine veliaht olan küçük oğlu Giyaseddin Keyhüsrev'in tahta çıkışı esnasında başının üzerine para saçılması; Harzemşahlar Devleti sultanı Alaaddin Tekiş (1172-1200) başkent Hamedan'da Abbasi Halifesinin elçilerini kabul ederken ayaklarının altına atlas serip başlarından altın saçması vb. hadiseler örnek olarak verilebilir. Bu geleneği Osmanlı döneminde de görebiliriz. Osmanlı sultanlarının tahta çıktığında dağıttıkları ulufe de saçı saçmanın değişmiş şeklidir. (İbni Bibi 1957: 39; Kafesoğlu 1998; 136) ; Saçı için bkz. (Gönüllü 1986/89; 9-11). 
atı hediye ettiğini biliyoruz (Turan 1988, 29). II. Glyaseddin Keyhüsrev avladığı hayvanların bir kısmını öldürmüyor, onları sarayında besliyordu. Hatta ölümü de sarayında beslediği bir kaplanın saldırısıyla olacaktır (Simbat 1946: 87; Turan 1977: 628; Turan 1988: 29). Ancak av seferleri toylar konusunda I. Alaeddin Keykubat'a ayrı bir bahis açmak gerekiyor. Çünkü o, Selçuklu Sultanları içinde av yapmayı ve büyük toylar düzenlemeyi çok seven bir sultandır. Ona, fırsat buldukça özellikle barış zamanlarında sürek avları düzenlediği için avcı lakabını takmak yerinde olur sanırız. Toylardan sonra Alaeddin Keykûbat genellikle gûy ü çevgân oynar, rûd ${ }^{6}$ sesi dinlerdi. Devletin idarî mekanizması avhanelere taşınır, önemli kararlar buralarda verilebiliyor, hatta elçileri burada karşılanıyordu. Sultan bu tip törenleri çok sevdiği için ölümü de böyle bir tören akabinde olmuştur. Büyük askerî merasim ve bayram tebrikinden sonra hazırlanan ziyafette, I. Alaeddin Keykubat yediği kuş etinden zehirlenmiştir (İbn Bibi 1957: 461; İbn Bibi 1996: 456). Sultan Alaeddin'in ağabeyi Sultan I. İzzeddin Keykavus da çok olmasa da av sonrası toylar (han-1 yağma) düzenlerdi. Özellikle bu ziyafetler Cuma sabahı yapılırdı (Turan 1947: 570). Mesela Sultan Ermeni seferinden sonra Kayseri'de emirleri (havas-ı ümera) ile birlikte görevleri aksatmayacak şekilde av ve yemekler düzenlemişti (İbn Bibi 1957: 182; İbn Bibi, 1996: 200). Sultan Kayseri'de iken Ermeni kralı hediyeler göndermişti ve bu hediyeler arasında bâz ${ }^{7}$ ve şahin bulunmakta idi (İbn Bibi, 1957: 169; İbn Bibi, 1996: 170; Turan, 1988: 28; Özaydın, 1991: 103). Çünkü kartal, şahin, doğan, atmaca gibi yırtıcı kuşlarla avlanmak için bu kuşların ava alıştırılması gerekiyordu8. Av kuşlarının yetiştirilmesi ve bakımı devlet teşkilatında önemli bir yer teşkil etmekte idi. Emir-i Şikarlar (bâzdar) bu teşkilâtın başı idi. Bu konu aşağıda anlatılacaktır.

Sadece Sultanlar av ve av etine düşkün değillerdi, emirler de av yapıyor ve av etini sofralarından eksik etmiyordu. Bu genellikle keklik olurdu. Saraya bağlı avcılar sürekli ava çıkarak özellikle keklik gibi eti kıymetli hayvanları avlarlardı. Sultanın ve ümera'nın sofrası kekliksiz bırakılmaz idi. Buna hem İbn Bibi hem de Yazıcızâde Ali'de geçen bir olay güzel bir örnektir. I. Gryaseddin Keyhüsrev ve I. İzzeddin Keykavus saltanatının tamamı, I. Alaeddin Keykubat döneminin başına kadar Türkiye Selçuklu devletinin en büyük emiri olan Melikü'l-ümera Seyfeddin Ayaba, "şiddetli soğuğun dondurucu kışın hüküm sürdüğ̈̈ zemherinin şiddetinden ve dondurucu soğuktan ateş küresinin (güneş) nefesinin tıkandığı bir sırada sofrasında kızarmış kekliğin eksik olduğunu görünce hemen buyruğu üzerine sofra sorumlusunu (han-sâlar), hazır ettiler. O, sofra sorumlusuna hiç duymadığı ă̆ır sözler söyledi. O zaman sofra sorumlusu, "Şiddetli soğuktan buzun fazlalı̆̆ından avcılar ava çıkamadılar" cevabını verince derhal şehri arayıp keklik bulsunlar. Ĕ̆ger bundan sonra sofrada keklik görmezsem, o cahil başına ne geleceğini sen düşün" diye çıkışmıştı (İbn Bibi 1957: 204; İ̉n Bibi 1996: 222; Yazıcızâde 2009: 327). Aşağıda anlatılacağı gibi Alanya'nın (Alaiyye) fethinden sonra burada yapılan köşk denilen ancak av seferlerinin yapıldığı yer olan binalar Sultanların dışında Selçuklu ümerasına da aitti. Tabii ki halk da gerek zevk için, gerekse ticaret maksadıyla yaban hayvanlarını avlamakta çarşı ve pazarlarda satılmakta idi (Mevlana 1981: 365; Mevlana 1990: 41). Mevlana Celaleddin- Rumî’nin eserlerinde bu konu ile ilgili geniş bilgiler

6 Rûd eski telli çalgı aletidir. Orta Çağ Azerbaycan klasiklerinin eserlerinde yer almıştır. Esasen, saray çalgı aleti sayılır. (Devellioğlu 2001: 896; İbn Bibi, 1957: 352-54, 356,418,424. Guy-u Çevgan, İngilizlerin golf oyununa benzer şekilde, meydan topunun atlılar tarafından uçları eğri değneklerle atılması esâsına dayanan şark oyunu. (Pakalın 1983: 359; Devellioğlu 2001: 158).

7 doğan [kuş], şehbaz, şahin, (Devellioğlu 2001: 74).

8 Kuşlarla avlanmanın çok eski bir geçmişi olmasına ve Hint-Avrupa kavimleri tarafından da bilinmesine rağmen, bu usul Avrupa'da Ortaçağa kadar bilinmemekte ya da unutulduğu ve Avrupalılara Endülüs ile Sicilya'da yeniden öğretildiği anlaşılmaktadır. Avcılık, hükümdar aileleri ile erkek ve kadın diğer aristokratların en büyük merakı olmuş, saraylarda, hatta orduda avcı birlikleri ile yüksek dereceli yönetici kadroları oluşturularak, avcılığa resmî bir hüviyet kazandırılmışır. (Erdem 1991: 101). 
vardır. Mesela doğan kuşları ile av köpeklerinden istifade edilerek veya çeşitli tuzaklar kurularak yapılan kuş avcılığına sıkça temas edilmektedir (Mevlana 1990: 196, 210; Özbek 2001: 41-58). Tilki, geyik, tavşan ve çakal avlanan yaban hayvanları arasında idi (Mevlana 1981: 993).

Büyük Selçuklu Sultanlarının da av ve toy konusunda Türkiye Selçuklu Sultanlarından hiçbir fark yoktur. Mesela Tuğrul Bey ve Melikşah av yapmayı, sonrada büyük ziyafetler (toy) vermeyi çok severlerdi (Sadrud-Din 1999: 90; Turan 1988, 28). Tuğrul Beyin sabahları ziyafet verdiğini hatta ava gezintiye gittiği vakit büyük ziyafetler verdiğini biliyoruz (Turan 1988: 30). Tuğrul Bey, her ava çıkışta beraberinde 20 katır yükü yiyecek götürür, kırlarda mükellef sofralar kurdurup emirlerine ve o bölgenin halkına yedirmekten zevk alırdı. Melikşah'ın bir defasında bizzat kendi eli ve köleleri vasıtasıyla avladığı avın miktarı 10.000 kadar idi (Sevim 2000: 72). Sebepsiz yere hayvan kanı akıtmanın günahından korktuğu için 10.000 dinar sadaka vermeyi emrettiği rivayet edilir. Yine Ravendî temaşa maksadıyla avlanmanın hükümdarlara helal olduğunu yazar (Sadrud-Din 1999: 73). Melikşah av hayvanlarının ahvalinden haberdâr olmak isterdi (Çetin 2007: 183-192). Sarayında ve ikamet ettiği her yerde av hayvanlarını yanında bulunur, onlar ile hemdem olurdu. Onun bu haline binaen bütün beyler, maiyet, erkanı vezirler, şehzadeler de arzusuna göre hareket ederlerdi. Meclisinde daha çok Nuşirevan'ın Baznâmesi, Ebu'l-Bahrî'nin Cevahir-nâmesi okunurdu. Melikşah bundan dolayı alıcı kuşlar hakkında bir kitap yazdırmak kendi adına nispetle yâd ettirmek ister ve bunun üzerine Saydname-i Melikşahî adıyla bir eser yazdırmıştır (Bilge 1945: 174). Felhak b. Mehmed'e yazdırılan bu Farsça eser, daha sonra Fransızcaya çevrilerek pek çok kitaba kaynaklık etmiştir (Ü çbaş 1999: 22; İlhan-Şenel 2008: 260). Yine Nizamulmülk, gittikçe Türk ananelerinden uzaklaşarak bir İslâm sultanı gibi hareket etmek isteyen Melikşah'a, bu ananelerin henüz içtimai kudretini hissederek ecdadının yolundan devam etmesini tavsiye etmektedir. Semerkant seferinde Maveraünnehr halkının ve hususiyle Çiğiller'in sultanın gelişinden beri yemeğini yemediklerini belirtmektedir (Turan 1988: 31). Melikşah'ın yediği av etinden sonra rahatsızlandığını ve öldüğünü biliyoruz (İbn Kalânisî 1983: 200; İbn Hallikan 1948: 375). Yine Irak Selçuklu hükümdarı Sultan Mugis ed-Dîn Ebû el-Kâsım Mahmûd b. Muhammed b. Meliksah Av kuşları ve eğitimli köpeklere ilgi duyardı. Denildiğine göre 400 fersenk $^{9}$ av alanına sahip olup altın tasmalı ve altın işlemeli çullar içinde 400 tazı köpeği onun zincirlerine bağlıydı (Çetin, 2007: 189).

\section{Emir-i Şikarlar ve Görevleri}

Türkiye Selçuklularında Sultanın av işlerini düzenleyen emirlere Emir-i Şikar adı veriliyordu. Bu emirlerin Sipeh salâr-ı Kebir, Uluğ emîr es- Sayd, hâsbeg,(Çetin 2007: 189) gibi unvanları vardı. Büyük Selçuklularda da av işlerine bakan görevlilere Emir-i Şikar veya Bâzdâr deniyordu (Ravendî 1999: 262, 282). Büyük Selçuklularda Bâzdâr lakabıyla Yarınkuş adlı bir emiri biliyoruz (Turan 1988: 29). Yine aynı şekilde Harezmşah Devletinde emir- şikar unvanlı emirlere rastlıyoruz. Harezmşah devletinin son sultanı Celaleddin Harezmşah'in emir-i şikarı Seyfeddin Tarâb idi (Uyumaz 2003: 53). Aynı şekilde Safavî Devletinde de Mirşikarlık, avcıbaşıllk veya emir şikarbaşı unvanlı şahıslara rastlıyoruz ki devletin özellikle kuruluş döneminde avcılık çok öne çıkmaktadır (Şükürov 2009: 57). Osmanlı Devletinde ise bu görevliler Şikar Ağaları deniyordu. Bu ifadeden anlaşıldığı üzere birden fazla Şikar Ağası vardı. Bunlar Çakırcıbaşı, Şahincibaşı, atmacacıbaşı idi. Bunlar sarayın "bîrun" denilen dış hzmetler kısmına mesuplardı (Uzunçarşılı 1984: 421). Ancak bu üç şikar ağasından başka sarayın "Enderun" kısmında bulunan "doğancıbaşı" denen şikar ağasının başında bulunduğu "doğancılar koğuşu" vardı. Bunlar sultana av esnasında en yakın görevlilerdi (Işsk 1991: 113; And 1970: 20).

Yaklaşık 5,5 kilometreye denk gelen eski bir ölçü birimi. 
Emir-i Şikar bulunduğu konum itibarıyla mühim bir yer işgal ediyordu. Sultanın en yakınında bulunuyordu. Emir- şikar av merasimleri eğlenceleri av etleri, av için kullanılan malzemelerin tedariki kullanılması, düzeni ona aitti. Bu emirlerin komutasında bir miktar asker bulunurdu (Aksarayî 1944: 126). Çünkü Emir-i Şikarlar'ın vazifeleri bir kişinin yapacağı bir iş değildi. Emir-i Şikar'ın yanında ona yardımcı görevlilerde bulunurdu. Bunlara da av halkı denirdi. Av halkının başlıca görevi avlanmada kullanılmak üzere av kuşları ve köpeklerinin bakımını yapmak ve eğitmekti. Bu görevliler pars, tazı, zağar ve yırtıcı kuşları eğiterek ava alıştırmışlardır. Çakırcı, şahinci, atmacacı adı verilen görevliler, Emir-i Şikar'a bağlı idiler. Mesela Selçuklu sarayında bu görevlilerden bir gulâm, "elinde şahini ile avdan gelirken ( kuşunu ava alıştırırken) avda uzun süre güneş altında kalmasından dolayı susuzluk ciğerine tak etmiş olduğunu bundan dolayı, kırda elinde yoğurt çanağı bulunan yaşlı bir kadının elindeki çanağı kapıp şehre doğru kaçmaya başladığııı kaynağımız anlatır (İbn Bibi 1957: 83; İbn Bibi 1996: 65). Bunlar Osmanlı döneminde yaptıkları işlere göre Doğancılar, Çaylak Avcıları, Akbaba Avcıları, Atmaca Avcıları gibi isimler almışlardır (Türkmen 2009: 23). Merkeze bu kuşlar Cemaat-ı Sayyadân adı verilen belli yerlerde görevlendirilen avcı cemaatları tarafından avlanır şikar halkı denilen sarayda bulunan görevlilere eğitilmek üzere gönderilirdi. Bu Cemaat-ı Sayyadân yaptıkları iş karşılığ vergiden muaf tutulurdu. Bulundukları bölgede avcı kuş yetiştiriciliği yapmak (sayyad avcı kuşunu yakalamak için tuzak kuranlar), yuvalarının bulunduğu kayaları gözetlemek (kayacı, yuvaların bulunduğu kayalıkları gözetenler), yavruları eğitmek (yavrucu, yavruları eğiten) gibi görevleri vardı (Işık 1991: 114; Uzunçarşılı 1984: 422-423). Bunlar Türkiye Selçuklular'ı döneminde avlaklara yerleştirilen Türkmenler arsından seçiliyordu. Mesela Selçuklu Sultanlarının en önemli avlakı olan Alanya ve çevresine yerleştirilen Çiğilin, Salur ${ }^{11}$, Avşar ${ }^{12}$, Türkmen Boylarının alt obalarından seçilmiş̧tir. Bunlar Bahşiş ${ }^{13}$, Keşefli, Sarıkeçililer ${ }^{14}$, Tosmur ${ }^{15}$, Dimliler (Dimalacami) (Saraçoğlu 1989: 348), Töngüşlü Tekelu, Avsal' ${ }^{16}$ Payal(( Haytalar) ${ }^{17}$, gibi obalardan seçilmiş olmalılar. Ayrıca bu bölgede XVI. yy. ait Osmanlı kayıtlarında Cemaat-ı Sayyadân (avcı cemaatları) in ve avlanan hayvanlardan alınan vergi kayıtlarının ${ }^{18}$ olması görüşümüzü desteklemektedir. I. Alaeddin Keykubat Alanya'da avı Gedevet yaylası denilen muhitte yapıyordu. Bu bölge sahile çok yakın idi. Gedevet (Gedavet) Konya'da olduğu gibi Alanya'da da "Yazın esen hafif rüzgâr" demektir (Derleme Sözlügü 1979: 1966-67). Osmanlı kayıtlarında bu bölge Turnalıtâs olarak geçmektedir ${ }^{19}$. Ancak halk arasında bu zamanla

10 Tuğrul Bey zamanında bile halk arasında Çiğil Türkmenlerine, Cikili dendiğini biliyoruz. Bizce Alanya'daki Cikcilli adı da Çiğil Türklerinden gelmektedir. (Nizamülmülk 1999: 89; Eröz, 1983: 232).

11 F. Köprülü'ye göre, Karaman Oğullarının kurucuları Avşar boyundan olmasına rağmen Avşar boyu bölgeye Salur boyu ile karışık olarak gelmiştir. (Tekindağ 1955: 317-330).

12 I Alaeddin Keykubat Avşar Türkmenleri, XIII. yüzyilin ilk yarisindan itibaren devam eden Mogol istilâsi sirasinda ülkelerini terk ederek önce Azerbaycan ve Sirvan taraflarına gelmisler ve buradan Anadolu'ya geçerek Türkiye Selçuklu Sultanı Alâeddin Keykubad (1220-1237) tarafindan Ermenek vilâyetine yerleştirilmişlerdir (1228). Başlarında Nûre Sûfî b. Sâdeddin isimli bir reis bulunuyordu. Ereğli ve Silifke taraflarinda başarılı akınlar yaptıgı bilinmektedir. Ancak Avşar Türkmenlerinin nufüzü çok fazla idi. Avşarlar Silifkeden Alanya'ya kadar uzandıkları bölgeyi şenledirdikleri söylenebilir.( Tekindağ 1955: 319-20).

13 Bu Türkmen obası da Avşar boyunun bir alt obasıdır. Hadim Ermenek, Anamur Gülnar, Mut, Alanya, Tarsus bölgelerinr yerleşmişlerdir.

14 Sarıkeçililer'in Oğuz boylarından hangisine mensup olduğunu tam olarak bilemesek de, yayıldıkları alan itibarıyla Avşar boyuna mensup olsa gerektir. (Türkay 1979: 657).

15 Bu Türkmen obası da Avşar boyunun bir alt obasıdır.

16 Avsal ismi de Avşar kelimesinin değişmişş şekli olabilir.

17 Avşarların bir kolu olan Haytalar'ın adı halk ağzında Avsallar şeklinde yaşamış olması mümkündür. ${ }^{18}$ Ankara Tapu Kadastro Genel Müdürlüğü, Kuyûd-1 Kadime, Alaiyye Mufassal Tahrir Defteri, No: 172, vr. 16b. 19 Ankara Tapu Kadastro Genel Müdürlüğü̈, Kuyûd-ı Kadime, Alaiyye Mufassal Tahrir Defteri, No: 172, vr. 44a 
Türbelinas olmuştur. Alaeddin Keykubat'ın emirlerinin bu bölgeyi çok iyi tanıdığı bugün adı Türktaş olan köy'ün Celaleddin Karatay'ın kardeşi Urumtaş tarafından kurulmasından bellidir ${ }^{20}$.

Tabii ki avlarda sadece kuşlar değil köpeklerde kullanılıyordu. Bunu antlaşmalarda bile görebiliyoruz. Kösedağ savaşında Moğollarla yapılan antlaşma sonucunda maddeler arasında avcı köpekleri verilmesi de vardı (Turan 1971: 445). Bunun nasıl ki sarayda kuşları eğiten görevliler varsa, köpeklere talim yaptırıp eğiten görevliler de vardı. Bunlara da Sekbancı deniyordu. Bunların içinde Turnacı denilen kuşları takip ve iz sürmeye yarayan köpekleri talim ettiren görevliler de vard1.

Emir- Şikarlar Sultan ava gittiği zaman eğitilmiş kuşları av halkı denen görevliler kollarında kuş taşırlar, Sultan hangi cins kuşu isterse Emir-i şikar o kuşu alır verirdi (Kahraman 1995: 151, 191-200, 202-205, 207-210, 213-217, 219, 220, 224-226, 228-232). Bu tarz av sahnelerinin Türkiye Selçuklular dönemi tasvirlerinde görebiliyoruz. Buna en güzel örnekler Konya Alaeddin Sarayı çinilerinde ve yukarıda bahsettiğimiz Afyon Boyalı köyden Afyon müzesine götürülen figürlü mezar taşında görebilmekteyiz (Otto-Dorn 1959: 63-76). "Burada bir atın gemliğinden tutmuş kaftanlı bir figür, atın üzerindeki avcı sol elinde bir şahin tutar, diğer eliyle uzun mızră̆ını av hayvanını saplayıp havaya kaldırmıştır. Atın önünde av hayvanı olması gereken başka bir hayvan dikey olarak yer alır. İkinci atlının elinde avda gürültü yaparak kuşların havalanmasına yarayan davul, tokmak, veya benzer aletler bulunur (Öney 1967: 128-129). En arkadaki süvarisiz at, bu atl tarafindan çekilir. Arkada iki atlı daha vardır. Atlıların önünde yay bir şahinci vardır". Bu tasvir bize Sultanların nasıl av yaptıklarını ortaya koymaktadır. Buna göre Sultan atın üzerinde durmakta, Atın gem'ini tutan görevli Emir-i Şikar olmalıdır. Diğerleri de sarayda görevli av halkıdır. Bu görevliler eğittikleri kuşları av esnasında Sultana sunmaktadırlar.

Emir-Şikarlar (Bazdârlar) (şahinci ve kuşçular) kulluk ve mülazemette bulundurması, şahinleri kuşlara saldırmakta ihtiyatlı davranması, sürgün avında kuş ve hayvanları halka haline (kürenc) getirme zamanında cesur ve marifetli avcıları (bâzdâr) hizmetinde tutması ve kuşların avlanma mevsiminde avcıları pusuya yerleştirmesi gibi görevler onların en önemli görevleridir (Turan 1988: 28; Uzunçarşı1ı 1988: 162-166). Emir-i Şikarlar bazen maaşlara talim edebiliyorlar ya da ikta alabiliyorlardı.

I. Alaeddin Keykubat zamanında Sadedin Köpek Emir-i Şikar idi (İbn Bibi 1957: 353, 665; Eflakî, 1989: 310). Sadeddin Köpek bu görevi devletin imaret (mimarbaşllı) görevi ile birlikte yürütüyordu. Sultanın Konya'dan Antalya ve Alanya arasında kış başlangıcı ve bahar dönüşü seyahatlerinde yol kenarında bir tepenin eteğinde inşâ ettiği Kubâd-âbâd şehri meyve ağaçları ve yeşillikleri, suları, havası ve gölün manzarası ile çok şirin bir yer idi. Bu güzel yer Sultanın dikkatini çekince o zaman mimar ve av işleri (Emir-i Şikar) emîri bulunan Sadeddin Köpek'e burada, bu güzel yerde, bir 'mamure yapmasını emretti. 1228 senesi baharında Erzincan seferi için Konya ve Kayseri'ye dönerken, yolda Kubâd-abâd'a uğradı. İnşaatın tamamlandığını gördü ve çok beğendi. Sultan her sene Akdeniz sahillerine gider ve oradan dönerken bir müddet de burada yaşar; eğlenir ve dinlenir, avlanırdı (İbn Bibi 1957: 352-54, 356,418, 424). Bu bilgiler bize gösteriyor ki, özellikle I. Alaeddin Keykubat döneminde Emir-i Şikar'ın görevi görev sorumluluk alanları geniş idi. Başka bir görevi üzerinde bulundurabiliyordu. Sultan av

20 Celaleddin Karatay'ın kardeşi olan Kemaleddin Urumtaş, aynı zamanda hekimdi. Devlet hizmetinde Emir-i sipahsalar olarak görev yapmıştır. Karatay Medresesi'nden önce ve onun karşısına bir medrese yaptırmıştır. Aynı zamanda Konya'da Hoca Fakıh Türbesi civarında bir de mescit yaptırmıştır. Hayatı hakkında bilgiler azdır. Büyük ihtimalle Alaeddin Keykubat'ın ölümünden sonra Sadedin Köpek'in takibatından kurtulan ve daha evvel çok iyi bildiği, saklanmaya müsait bir bölge olan Alaeddin Keykubat'ın av sahası olan Gedevet ve civarına yerleşen ve buraya adını veren büyük Selçuklu emiridir. 1967 yılında çıkartılan bir yasayla Türkiye genelindeki birçok yerleşim alanları gibi Urumtaş Türktaş olarak değiştirilmiştir. (Konyalı 1946: 283). 
esnasında yanında vezir bulunmadığı için Tuğra mansıbı (divan-1 resâil ve divan-ı inşa) veziri olurdu (Burslan 1999: 102). Aynı şekilde Celaleddin Harezm-ah, Emir-i şikarı Seyfeddin Tarab'a elçilik görevi vermişti (Uyumaz 2003: 53).

Ayrıca Türkiye Selçuklu devletinin yıkılış döneminde bile küçük bir çocuk olarak tahta çıkan, gençlik çağında da ölen III. Giyaseddin Keyhusrev'in bile emir-i şikarı vardı. Onun adı da Kılavuzoğlu Tuman Bey idi (Eflakî 1989: 254).

\section{Sonuç}

Türkiye Selçuklular'ında av geleneğine bir aşk derecesinde bağlı Alaeddin Keykubat ve dönemini ayrı değerlendirmek gerektiğine inanıyoruz. Çünkü Selçuklu topraklarında bulunan şikarhanelerin bir çoğunun bu dönemde yapılmıştır. Önemli kararların alınması, elçilerin karşılanması hep sultanın av esnasında yapılmıştır. Sultanların av işlerini düzenleyen Emir-i Şikar ve kendisine yardımcı olan av halkı denen görevlilerle birlikte Selçuklu sarayında belli bir nüfuza sahiptiler. Bunlar Selçuklu Türkiye'sinin belli yerlerinde bulunan avcı cemaatı (Cemaat-1 Sayyad) adı verilen görevliler tarafından gönderilen avcı kuşları eğitip, Sultana av esnasında sunuyorlardı. Selçuklu Sultanlarının av törenleri hakkında geniş kaynaklara sahip olmadığımız için detaylı bilgiler vermemiz mümkün gözükmüyor. Ancak bu törenler Osmanlı Sultanlarının av merasimlerinin bir protipi olduğunu söyleyebiliriz.

\section{Abstract}

Hunting has a background as long as history of humanity. Human beings strived to meet their needs and survive at first until they used rifles and made up several rituals. Hunting was just at the centre of Turks' lives because of the geography they lived. While they survived and met their needs with the meat of the animals hunted, they also made boots with their leathers, clothes and kalpaks with their furs, bows and musical instruments with their horns and skiing tools with their bones, and they considered hunting as the most important military exercise to get ready for a battle. Hunting was performed as battues and bird hunting.

Battue is a kind of hunting which both improves soldiers physically and develops their manoeuvrability and is a range of activities which goes on for days. Battues were long-termed. However, bird hunts which were performed for a short time by a few crews in the hunting areas near the palace without ceremony. The Sultans of the Sultanate of Rum sustained a national tradition called toy (feast). This tradition was the sign of dominance of Seljuks as it was for all Turkic States. When a sultan succeeded the throne, he had to display his generosity and wealth. In other words, as Bilge Khagan pointed "he should feed the hungry nation and clothe the naked nation" (Ergin 1980: 25, 19). For this reason, he used to disburse and he organized great toys (feasts) after each great hunting ceremony. It is possible to see it in building hunting lodges. These constructions were built up in a part of large lands that had the perfect viewpoint as a location. It means these toys were organized in large places. After coming back from hunting, great feasts were given with the game meat and these feasts were enriched with music, chovgan, javelin and chess. There were emirs called hunting emirs (Emir-i Şikar) who were just responsible for hunting and did everything related to hunting even training of the birds that would be used in hunting ceremonies. 


\section{KAYNAKÇA}

ATEŞ, Ahmet (1966). ”Bir Açılama”, Belleten, XXX, Ankara: s, 459-466.

Ankara Tapu Kadastro Genel Müdürlüğü, Kuyûd-ı Kadime, Alaiyye Mufassal Tahrir Defteri, No: 172, vr. 44a.

AND, Metin (1970). "XVI. Yüzyılda Av ve Avc1lık”, Hayat Tarih Mecmuası, S.12, İstanbul: s. 17-21.

BAYAT, Fuzuli (2009). "Sosyo-Ekonomik Bağlamlı Avdan Bozkır Eğlence Avlarına Geçiş”, Acta Turcica, I, s. 1-11.

BAYKARA, Tuncer (2005). Türk Kültürü, İstanbul.

BERBERCAN, M. Turgut (2010). "Türk Dili ve Kültürü Açısından Babur-nâme'de Avcılık” AÜ. Türkiyat Araştırmaları Enstitüsü Dergisi, S. 42, Erzurum: s. 11-34.

BİLGE, Rifat (1945). “İstanbul Kütüphanelerinde Bulunan. Baznameler” İ.Ü. Türkiyat Mecmuasl, VIII/ 8, İstanbul: s. 169-182.

BURSLAN, Kıvameddin (1999). Irak ve Horasan Selçukluları Tarihi, Ankara: TTK Yay.

CAFEROĞLU, Ahmet (1972). "Türklerde Av Kültürü ve Müessesesi”, VII. Türk Tarih Kongresi -25-29 Eylül 1970- Kongreye Sunulan Bildiriler, I, Ankara: s. 169-174.

ÇETIN, Altan (2007). "Yahya Kazvını̂’nın Lubb Et-Tevârıh'inde Selçuklularla Alâkalı Bılgıler" Gazi Türkiyat Dergisi. S. 1, Ankara: s. 183-192.

ÇORUHLU, Yaşar (1997). “Türk Sanatında Av Sembolizmi”, Arkeoloji ve Sanat, S. 76, İstanbul: s. 13-25.

DEVELLIOĞLU, F. (2001). Osmanlıca- Türkçe Ansiklopedik Lûgat, Ankara.

Derleme Sözlüğ̈̈ (1979). VI, Ankara: TDK yay.

DOHSSON, Muraja, Moğol Tarihi, çev. Mustafa Rahmi (1340-1342). İstanbul: Matbaa-i Amire.

HÜSEYNÎ, Ebu'l-Hasan Sadrud-Din, Ahbaru's- devletu's-selçukiyye, çev. N. Lugal, (1999). Ankara.

ERGIN, Muharrem (1980). Orhun Abideleri, İstanbul. (1989). Dede Korkut Kitabı, I, Ankara.

ERÖZ, Mehmet (1983). Milli Kültürümüz ve Meselerimiz, İstanbul.

ERGÜZEL, M. Mehdi (2009).__Kitab-ı Bâz-nâme-i Padişahi, Ankara.

EFLAKİ, Menakıbu'l- Arifin, II, çev. T.Yazıcı, (1989). İstanbul.

ESIN, Emel (2006). Türklerde Maddî Kültürün Oluşumu, İstanbul.

ERCILASUN, Ahmet Bican (1992). Karşılaştırmalı Türk Lehçeleri Sözlüğü, I, Ankara.

ERDEM, Sargon (1991).“Av”, DİA, C. 4, İstanbul.

ERSAN, Mehmet (2006). "Türkiye Selçuklularında Devlet Erkânının Eğlence Hayatı”, Tarih İncelemeleri Dergisi, XX/I, s. 87-86.

ERAVŞAR, Osman (2002). “Az Bilinen Bir Selçuklu Köskü: Kızıl Köşk”, VI. Ortaçag ve Türk Dönemi Kazı Sonuçları ve Sanat Tarihi Sempozyumu ( 8- 10 Nisan 2002 ), ed. M. Denktaş, Y. Özbek, A.S. Aslan, Kayseri: s. 365- 381.

GENÇ, Reşat (1981). Karahanlı Devlet Teşkilatı, Ankara.

GÜVEN, Özbay (1999). Türklerde Spor Kültürü, Ankara.

GÖNÜLLÜ, A. Riza (1986). "Saçı Adetine Dair Notlar” Türk Folkloru Dergisi, s. 9-11.

İBN BİBI, El- Evâmirü'l- alaiyye fi'l-umuri'l- Alaiyye I, Tıpkı Basım, nşr. A. Erzi- N.Lugal (1957). Ankara.

İBN BİBİ, El-Evâmirü'l-Alaiyye fi'l-Umuri'l-Alaiyye (Selçuk-nâme), I, çev. M. Öztürk (1996). Ankara: Kültür Bakanlığı yay.

İBN KALÂNISÎ, Tarihu Dımaşk, thk. Süheyl Zekar (M.1983/H.1403). II, Dımaşk.

İBN HALLIKAN, Vefeyatü'l A'yan, thk. Muhyiddin Abdülhamid (1948). IV, Kahire.

İLHAN, Nadir -Mustafa Şenel (2008). "Dîvânu Lugat'it Türk'e Göre Av, Avcılık ve Hayvancılıkla İlgili Kelimeler ve Kavram Alanlar" Turkish Studies, 3/1 Winter, s. 259-277.

IŞIK, Ahmet (1991). "Avc1", DIA, C. 4, İstanbul: s. 113-115.

KAHRAMAn, Atıf (1995). Osmanlı Devletinde Spor, Ankara.

KAFESOĞLU, İbrahim (1998). Türk Milli Kültürü, İstanbul. --(1956). Harzemşahlar Devleti Tarihi, Ankara.

KAŞGARLI MAHMUD, Divanü Lügati' - Türk, I, çev. Besim Atalay (2006). Ankara.

KONYALI İ. Hakkı (1946). Alanya (Alâiyye), İstanbul.

KÖYMEN, M. A. (2000). Alp Arslan ve Zamanı, III, Ankara.

LINDNER, Kurt (1972). Beiträge zu Vogelfang und Falknerei im Altertum, Berlin.

MÜLER, Detlef (1965). Studien zur mittelalterlichen arabischen Falknereiliteratur. Berlin. 
MEVLANA, Mesnevi,I, çev. Veled İzbudak, (1981). İstanbul.

, Fihi Mâfih, çev. M. Anbarcioglu, (1990). İstanbul.

NIZAMÜLMÜLK, "Siyaset-nâme, çev. M. A. Köymen (1999). Ankara.

OTTO-DORN K. (1959). “Türkische Grabsteine mit Figurenreliefs” Ars Orientalis, III, Michigan: s. 63-76.

ORAL, M. Zeki (1949). "Kubad abad Bulundu” Anit Dergisi, 1/X, Konya: s. 1-49.

ÖNDER, S. Yılmaz (2009). "Oğuz Resmi İle avlanma” Acta Turcica, 1/I, s. 12-21.

ÖLMEZ, Zühal (1996). Şecere-i Terâkime, Ankara.

ÖNCÜL, Kürsat, (2009). “Türk Kültüründe Av Ceza İlişkisi” Turkish Studies, Volume 4/3 Spring, s. 16811688.

ÖNEY, Gönül (1967). "İran Selçukluları ile Mukayeseli olarak Anadolu Selçuklularında Atlı Avcı Sahneleri”, Anadolu (Anatolia), XI, Ankara: s. 121-138

------(1978). Anadolu Selçuklu Mimarisinde Süsleme ve El Sanatları, İş Bankası Kültür Yayınları, Ankara.

ÖZAYDIN, Abdülkerim (1991). “Av”, DİA, C. 4, İstanbul: s. 101-104.

ÖZBEK, Süleyman (2001). "Türkiye Selçuklularında Kültürel Hayat; Mevlana'nın Fihi Mafih ve Mesnevi'sine göre”, AKÜ. Sosyal Bilimler Dergisi, 3/1, Afyon: s. 41-58.

PAKALIN, M. Zeki (1983). Tarih Deyimleri ve Terimleri Sözlüğü, İstanbul.

RÂVENDÎ,, Râhatü's-Sudûr ve Ayetü's-Sürûr, çev. A. Ateş, (1957). Ankara.

REDFORD, S. (2000). Seljuk Garden And Pavilions Of Alanya, Turkey, BAR. International Series 893, Oxford.

(2008). Anadolu Selçuklu Bahçeleri, İstanbul.

ROUX, J. Paul (1994).Türklerin ve Moğolların Eski Dini, İstanbul.

SARAÇOĞLU, Hüseyin (1989). Akdeniz Bölgesi, İstanbul.

SEVIM, Ali (1982). Biyografilerle Selçuklu Tarihi, İbnü'l-Adim Bugyetü't- Taleb fi Tarihi Haleb (Seçmeler), Ankara.

Simbat, Başkumandan Vekayinamesi, (951-1334), çev. H. D. Andreasyan (1946). İstanbul.

SÜMER, Faruk (1980). Oğuzlar (Türkmenler), Tarihleri, Boy Teşkilatlarl, Destanları, Ankara.

SÜMER, F.- A. Sevim (1971). İslâm Kaynaklanna Göre Malazgirt Meydan Savaşı, (Metinler ve çevirileri) Ankara.

SÜSLÜ, Özden (1989). Tasvirlere göre Anadolu Selçuklu Kıyafetleri, Ankara: Atatürk Kültür Merkezi Yay.

ŞÜKÜROV, Qiyas (2009). "Safevîlerde Av Geleneğinin Oluşumu ve I. Şah İsmail Dönemi Av Merasimleri”" Acta Turcica, (Ed. Emine Gürsoy Naskali- Hilal Oytun Altun), 1/I, Michigan: s. 56-71.

TANERİ, Aydın (1997).Türk Devlet Geleneği, Ankara.

TEKİNDAĞ, Şihabeddin (1955). "Karamanlılar”, $\dot{I} A$, C. 6, İstanbul: s. 316-330.

TURAN, Osman (1945). "Eski Türklerde Okun Hukukî Bir Sembol Olarak Kullanılması", Belleten, IX/35, Ankara: s. 305-318. (1977). “Keyhusrev II", IAA, C. 6, İstanbul: s. 620-629.

(1948). "Türkiye Selçuklularında Toprak Hukuku”, Belleten, XII/47, Ankara: s. 550-574.

(1999). Selçuklular Tarihi ve Türk İslam Medeniyeti, İstanbul.

(1971). Selçuklular Zamanında Türkiye, İstanbul. (1988). Türkiye Selçuklular'ı Hakkında Resmî Vesikalar, Ankara.

TÜRKAN, Kadriye (2008). “Azeri Masallarında Av Kültü ve Av Anlayışı” Millî Folklor, S. 80, Ankara: s. 70-76.

TÜRKMEN, Mustafa Nuri (2009). “Osmanlıda Av Seferleri”, Acta Turcica, 1/I, Micgihan: s. 22-32.

UZUNÇARŞILI, İ. Hakkı (1988). Kapıkulu Ocakları, I, Ankara. (1984). Osmanlı Devletinin Saray Teşkilâtı, Ankara.

UYUMAZ, Emine (2003). Sultan I. Alâeddin Keykubad Devri, Ankara: TTK yay.

ÜÇBAŞ, Kamil (1999). Avcının Temel Eğitim Kitabı, Ankara

YAVAŞ, Alptekin (2003). “Alanya-Çıplaklı Mahallesinde Bilinmeyen Bir Selçuklu Köşkü”, Ege Üniversitesi Edebiyat Fakültesi Sanat Tarihi Dergisi, S. XII, İzmir: s. 155-162.

(2007). “Anadolu Selçuklu Köşklerinin Plan Tipleri Üzerine Tespitler” Ankara Üniversitesi Dil ve Tarih-Coğrafya Fakültesi Dergisi, 47/1, Ankara: s. 203-227.

(2004). “Kayseri-Argıncık Haydar Bey Köşkü”, Ankara Üniversitesi Dil ve Tarih-Coğrafya 
Fakültesi Dergisi, 44/2, Ankara: s. 131-149.

YAVUZ, Ayşıl Tükel (2000). “Antalya, Kemer'deki Selçuklu Köşkü”, Emin Bilgiç Hatıra Kitabı, Yay. ve Haz. Oktay Aslanapa-Ekmeleddin İhsanoğlu, İstanbul: s. 279-289.

Yazıcızâde Ali (2009). Tevarih-i Âl-i Selçuk, haz. A. Bakır, İstanbul

YETKIN, Şerare (1972). Anadolu'da Türk Çini Sanatının Gelişmesi, İstanbul: İstanbul Üniversitesi Matbaası. 
EKLER

Ek-1

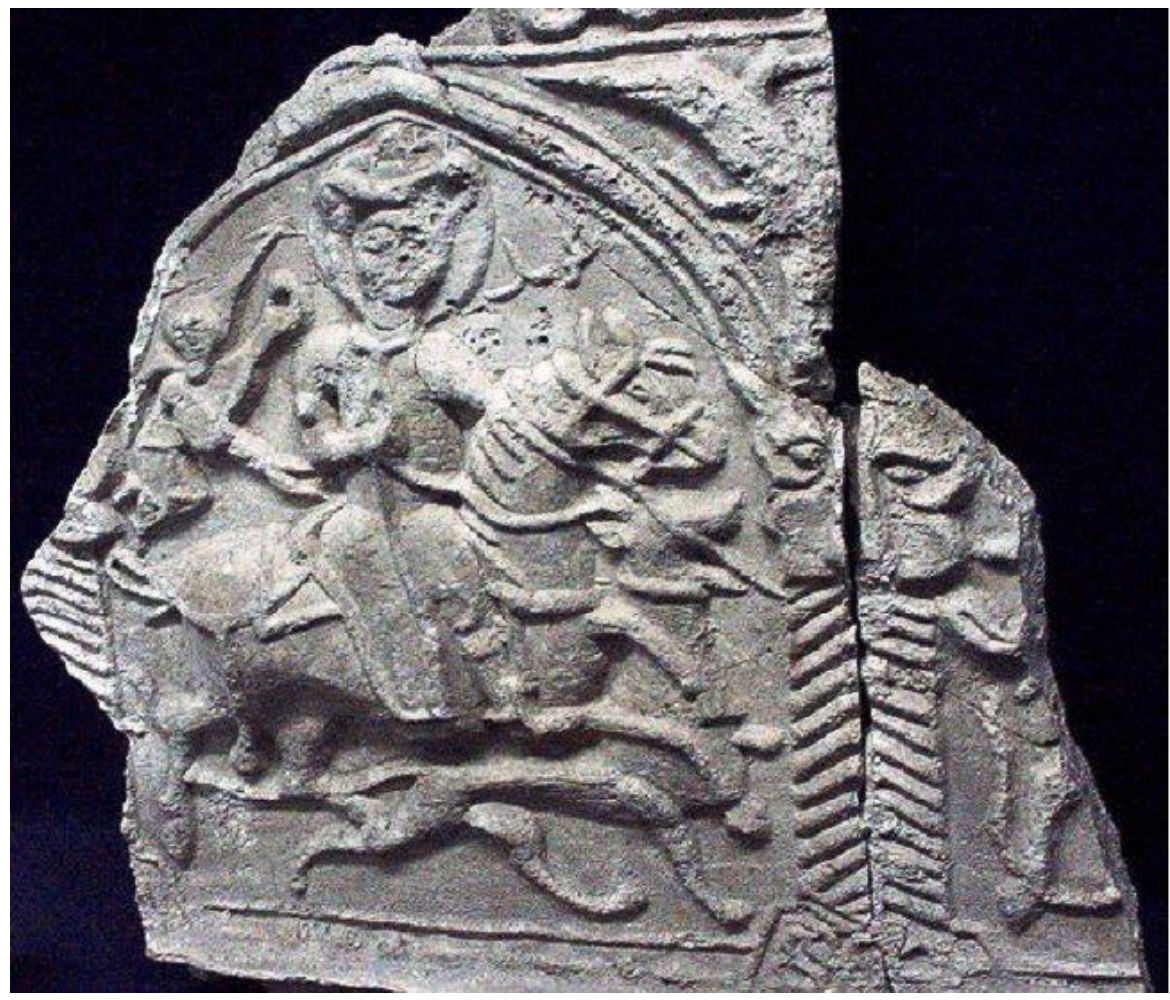

Ek-2

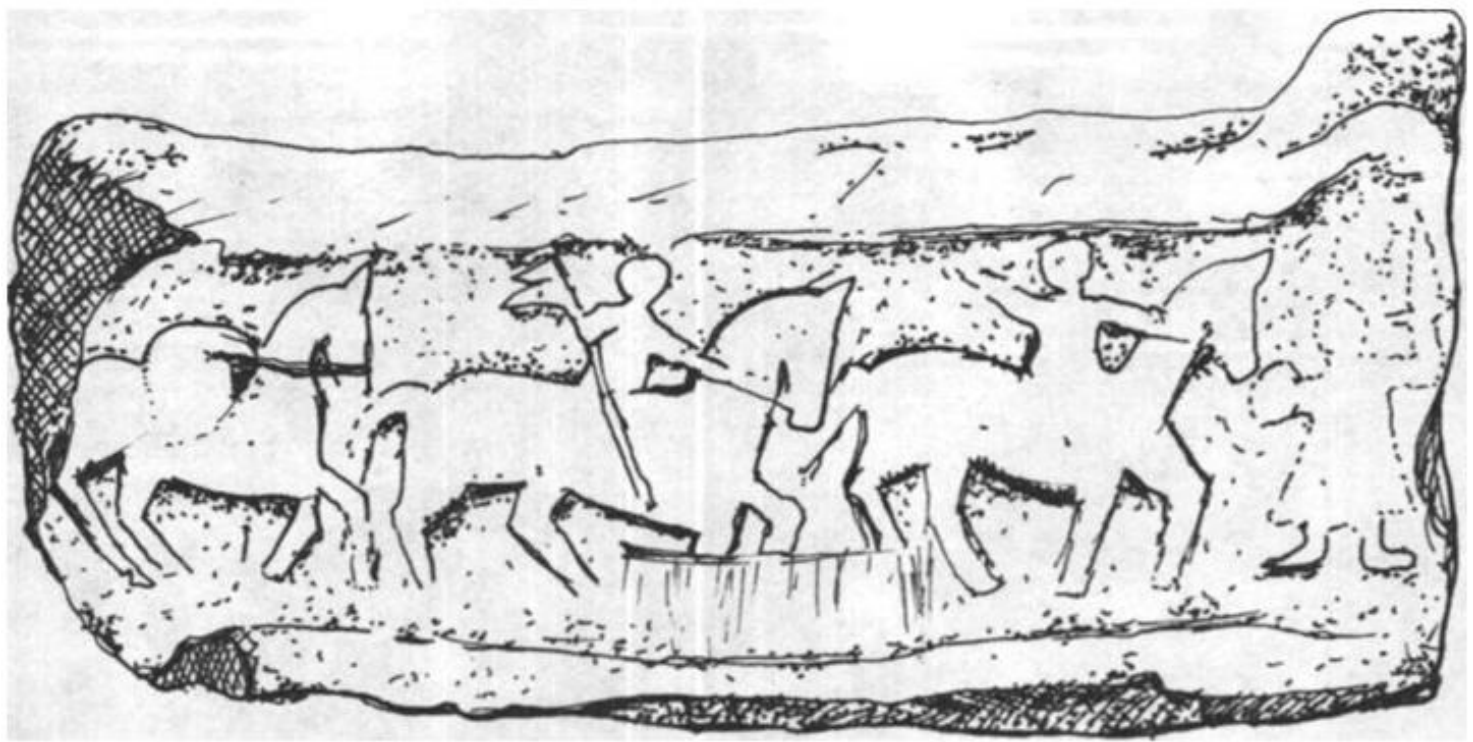

